\title{
The effect of gender and leisure preference on transformational leadership behaviour of high school students
}

\author{
Nurullah Emir Ekinci ${ }^{1 a}$, Umit Dogan Ustun $^{2}$, and Halil Bisgin ${ }^{2}$ \\ ${ }^{1}$ Dumlupinar University School of Physical Education and Sport, Kutahya/Turkey. \\ ${ }^{2}$ Dumlupinar University School of Physical Education and Sport, Kutahya/Turkey
}

\begin{abstract}
This paper aimed to investigate transformational leadership behaviors of high school students according to their leisure preference and gender. Randomly chosen 391 high school students from Kutahya voluntarily took part in the study. In the study Transformational Leadership Scale was used as data gathering tool and after evaluation of dispersion of the data Two-way Analysis of Variance was used as a hypothesis test. As a result, this study showed that transformational leadership behavior differs according to gender and also both leisure preference and gender have an effect on transformational leadership behavior of high school students.
\end{abstract}

Keywords: Transformational Leadership, Leisure Preference, Gender, High School Students

\section{Introduction}

Transformational leadership has rapidly become the matter of choice for much of the research of leadership theory, and in many ways the theory has attracted researchers. But what the theory includes? The answer of this question goes back to Burns' (1978) transformational and transactional leadership theory. According to this theory transformational leader has to be distinct from the transactional leader, where the latter is viewed as a leader who initiates contact with subordinates in an effort to exchange something of value, such as rewards for good performance or bilateral disclosure. At the other side of the leadership behavior, Bums viewed the transformational leader as one who engages with others in such a way that the leader and the follower raise one another to a higher level of motivation and morality [14].

As contrast to transactional leaders, transformational leaders have been characterized as one who articulates a vision of the future that can be shared with peers and subordinates, intellectually stimulates subordinates, and pays high attention to individual differences among people [11]. Transformational leaders seek new ways of working, seek opportunities

${ }^{\text {a }}$ Corresponding author: ekinciemir@gmail.com 
in the face of risk, prefer effective answers to efficient answers, and are less likely to support the status quo [14]. And according to Bass [13] transformational leaders fallowed because of their potential of charisma, inspiration etc.

Although the theory grew up in time and became world-wide [14], it was commonly used in management $[8]$, or in education $[9,10]$, in order to identify managers or teachers' leadership behaviors. But is it possible to mention transformational leadership theory in recreation organizations. Kraus [17] tries to give a possible answer in his book by defining the nature of leadership within recreation texts. Also for example Hayashi and Ewert [8] examined the relationship between transformational leadership behavior and emotional intelligence of outdoor leaders and in their research they found moderate and positive relationship between emotional intelligence and transformational leadership.

Traditional analyses of recreation leadership have two themes: an individual-centre approach to leadership behavior, and the location of leadership activities within the internal organizational context [16]. According to Karaküçük [21] general leadership and recreational leadership behaviors can be considered as similar in many ways. For example the expectations from a recreation leader can be to direct the group members to specific events or to guide them and to impress them. Also recreation organizations can vary from tracking to skiing and in order to achieve success, each organization needs recreation leaders.

So in this study it was aimed to investigate transformational leadership behaviors of high school students (individual-centre approach to leadership behavior as stated in [14]) according to their leisure preference and gender and following research questions were examined.

R1 Does leisure preference has an effect on transformational leadership?

R2 Does gender has an effect on transformational leadership?

\section{Method}

\subsection{Research Design}

In the study cross-sectional/survey design method was used. Cross-sectional/survey design is perhaps the most common design within the social sciences. According to this method data is collected once from the participant and relationships are identified from this data, and casual relationships may be suggested, which can then be generalized back to the population [6].

\subsection{Participants}

The data of the study collected from 391 high school students which were randomly selected from the high schools in Kutahya city center during second term of 2015-2016 education years. Random sampling method can be selected so that every individual is equal in the population there is the possibility that [3], the data's collected by the researcher by using face to face method. [3], face to face method provides a better communication between researcher and participant which increase reliability level of the study. 


\subsection{Measurement Tools}

In the study as data gathering tool in addition to personal information form Transformational Leadership Scale was used. Transformational Leadership Scale is a selfreport scale first developed by Başoglu [2] and revised by Ustun [5]. The scale has 8 items and one factor. Respondents/participants rated their level of agreement with the reason using a 5 point likert type scale anchored from strongly disagree (1) to strongly agree (5). In his study Ustun found the Cronbach alpha for the scale as .89 and Spearman-BrownCoefficient value as .84 . For this study the fit index of the scale recalculated and seen to have a good fit index [CFA fit Index Results were found as REMSEA= .060, RMR: .048, SRMR: .041 and CFI: .96].

\subsection{Procedure and Data Analysis}

In the study first the normality of the data examined via histogram graphs and assessing skewness and kurtosis values. According to analyses it was concluded that the data was normally distributed. Then reliability of the data gathering tool assessed with Cronbach's alpha statistical method. According to Seçer [4] Cronbach's' alpha is a common used method when assessing issues such as personality, interest and attitude with scales when the data shows normal distribution and evaluated with Likert type and has one dimension. In the present study Cronbach's was calculated as .73. And according to George \& Mellory [1] .73 is an acceptable value for social studies. In the previous studies because of the factorial structure of the scale was described we just used confirmatory factor analysis and assessed REMSEA, RMR, SRMR and CFI as fit index values. The CFA results showed that scale has alignment values for the sample of the study. Lastly for controlling the type 1 error Two-way Anova statistical method was used as hypothesis test. This method examines the influence of two different categorical independent variables on one continuous dependent variable [7].

\section{Findings}

Table 1. Descriptive Two-way Anova results

\begin{tabular}{|c|c|c|c|c|}
\hline \multicolumn{5}{|c|}{ Dependent variable: Transformational Leadership } \\
\hline Leisure Preference & Gender & $\mathbf{N}$ & $\overline{\mathrm{X}}$ & SD \\
\hline \multirow{3}{*}{$\begin{array}{l}\text { Home based } \\
\text { activities }\end{array}$} & Male & 45 & 3.79 & .51 \\
\hline & Female & 65 & 3.7 & .65 \\
\hline & Total & 110 & 3.74 & .60 \\
\hline \multirow[t]{3}{*}{ Sport activities } & Male & 101 & 3.56 & .37 \\
\hline & Female & 94 & 3.63 & .48 \\
\hline & Total & 195 & 3.6 & .43 \\
\hline \multirow[t]{3}{*}{ Social activities } & Male & 26 & 4.17 & .28 \\
\hline & Female & 60 & 3.49 & .54 \\
\hline & Total & 86 & 3.69 & .57 \\
\hline \multirow[t]{3}{*}{ Total } & Male & 172 & 3.72 & .45 \\
\hline & Female & 219 & 3.61 & .56 \\
\hline & Total & 391 & 3.66 & .52 \\
\hline
\end{tabular}


According to descriptive two-way anova results it can be seen that male participants', whose leisure preference we home based $(\overline{\mathrm{x}}=3.79 \pm .51)$ and social activities $(\overline{\mathrm{x}}=4.17 \pm$ .28) perceives more transformational leadership than females but female participants who do sport as a leisure preference perceives more transformational leadership than males $(\overline{\mathrm{x}}=3.63 \pm .48)$.

Table 2. Two-way Anova results (test of between subjects effects)

\begin{tabular}{lccccc}
\hline \multicolumn{5}{c}{ Dependent variable: Transformational Leadership } \\
\hline Source & $\begin{array}{c}\text { Type III Sum of } \\
\text { Squares }\end{array}$ & df & $\begin{array}{c}\text { Mean } \\
\text { Square }\end{array}$ & F & Sig. \\
\hline Leisure preference & 3.34 & 2 & 1.67 & 6.91 &, 001 \\
Gender & 4.37 & 1 & 4.37 & 18.03 &, 00 \\
Leisure preference * gender & 7.44 & 2 & 3.72 & 15.36 &, 00 \\
Error & 93.19 & 385 & .24 & & \\
Total & 5338.047 & 391 & & & \\
Corrected Total & 103.551 & 390 & & & \\
\hline \multicolumn{5}{l}{} \\
\hline
\end{tabular}

According to Two-way Anova test of between subjects effects results, effect of leisure preference $(F .05=6.91 ; p<.001)$, effect of gender $(F .05=18.03 ; p<.01)$ and common effect of leisure preference and gender $(\mathrm{F} .05=15.36 ; \mathrm{p}<.01)$ on perceived transformational leadership were found to be significant. When we look at descriptive results we can conclude that the effect of gender on perceived transformational leadership is in favor of male participants $(\overline{\mathrm{x}}=3.72 \pm .45)$ and according to Tukey's Hsd multiple comparison test results the differences between the effect of leisure preference are between participants whose leisure preferences were sport and social activities $(\mathrm{p}<.05)$.

\section{Results and Discussion}

The findings of the current research revealed information about possible effect of leisure preference and gender on transformational leadership. First the effect of leisure preference on transformational leadership was found to be significant and Tukey's Hsd test revealed the difference between participants whose leisure preference were sport and social activities. So it can be said that even the participants whose leisure preferences were home based got the highest score, this result found to be insignificant. And participants who choose social activities as leisure activities have the highest significant score. In contrast to this finding both Ustun [5] and Başoğlu [2] reported that the students who do sport as a leisure activity have the highest significant score rather than students who choose social activities.

Second the effect of gender on transformational leadership was found to be significant and descriptive statistics revealed this score was in favor of males. So we can say that males are more inclined to show transformational leadership behavior than females and therefore are more strive to motivate their followers to achieve beyond what was originally thought possible [19].

Third the common effect of both leisure preference and gender on transformational leadership was also found to be significant. So in the study we accepted all the three hypothesis and got answers to research questions. 


\section{Limitations and Implications}

This study is an exploratory study examining the possible effects of leisure preference and gender on transformational leadership behavior. Therefore have several limitations. First the sampling group was all high school students and chosen regardless of being recreation leader or not. So from an application perspective future studies may concentrate on different sampling groups and using comparisons with a normative sample and recreation leaders. Second in this study leisure preferences were limited with home based, social and sport activities. And also active or passive participation into these activities did not examine. So future studies may enlarge these activity types and consider participation type as active or passive.

Finally this study investigated participants' approach to transformational leadership behavior. So future studies may explore situational approach to leadership or reciprocal approach to leadership [20]. This study suggested that there is a connection between transformational leadership and recreation which seems to make sense, so future studies should continue to explore this and related questions.

\section{References}

1. George, D. \& Mallery, P., SPSS for Windows step by step: A simple guide and reference, 11.0 update (4th ed.). Boston: Allyn \& Bacon, (2003).

2. Başoğlu, U.D., Relationships between Participation in Recreational Activities and Leadership Behavior: A Study on the Secondary School Students, Turkish Journal of Sport and Exercise, 15 (2): 100-106, (2013).

3. Büyüköztürk, Ş., Kılıç Çakmak, E. \& Akgün, Ö.E., Karadeniz, Ş. ve Demirel, F. Bilimsel Araştırma Yöntemleri, Ankara: Pegem Akademi, 11. Bask1 (2012).

4. Seçer, İ. Psikolojik Test Geliştirme ve Uyarlama Süreci SPSS ve Lisrel Uygulamaları Ankara: Anı Yayıncılık, (2015).

5. Üstün, Ü.D. Lise Öğrencilerinin Rekreatif Etkinliklere Katılımları ve Cinsiyetlerine Göre Dönüşümsel Liderlik Eğilimlerinin İncelenmesi. 3. Rekreasyon Araştırmaları Kongresi 5-7 Kasım, Eskişehir, 133-138 (2015).

6. Gratton, C. \& Jones, I. Research methods for sport studies, Routladge, London 2nd edition, (2010).

7. Field, A. Discovering Statistics Using SPSS, Sage, London 3rd edition, (2009).

8. Ergin, C. \& Kozan, M.K. Çalışanların Temel Değerleri, Dönüşümsel ve Etkileşimsel Liderlerin Çekiciliği, Türk Psikoloji Dergisi, 19 (54): 37-51, (2004).

9. Korkmaz, M. Duyguların ve Liderlik Stillerinin Öğretmenlerin Performansı Üzerinde Etkisi, Kuram ve Uygulamada Eğitim Yönetimi, 43: 401-422, (2005).

10. Tahaoğlu, F. \& Gedikoğlu, T. İlköğretim Okulu Müdürlerinin Liderlik Rolleri, Kuram ve Uygulamada Eğitim Yönetimi, 15 (58): 274-298, (2009).

11. Yammarino, F.J. \& Bass, B.M. Transformational leadership and multiple levels of analysis, Human Relations, 43(10), 975-995, (1990).

12. Bums, J.M. Leadership, New York: Harper \& Row. (1978).

13. Bass, B.M. Does the transactional/transformational leadership transcend organizational and national boundaries? American Psychologist, 52, 130-139, (1997).

14. Lowe, K. B., Kroeck, K. G. \& Sivasubramaniam, N. Effectiveness correlates of transformational and transactional leadership: A meta-analytic review of the MLQ literature. The Leadership Quarterly, 7(3), 385-415,(1996).

15. Bass, B.M. Two Decades of Research and Development in Transformational Leadership, European Journal of Work and Organızatıonal Psychology, 8 (1): 9-32, (1999). 
16. Stokowski, P. A., Long, P. T. \& Nuckolls, J. S. Recreation leadership as a system of social ties. Journal of Park and Recreation Administration, 10(2), 67-77, (1992).

17. Kraus, R. Recreation leadership today. USA: Scott, Fothsman \& Company (1985).

18. Hayashi A. \& Ewert A. Outdoor Leaders' Emotional Intelligence and Transformational Leadership, Journal of Experiential Education 28 (3), 222-242, (2006).

19. Sivanathan, N. \& Fekken, G. C. Emotional intelligence, moral reasoning and transformational leadership. Leadership \& Organization Development Journal, 23(3/4), 198-204, (2002).

20. Russell, R. V. Leadership in recreation (Third ed.). New York, NY: McGraw-Hill Companies, (2005).

21. Karaküçük, S. Rekreasyon Boş Zamanları Değerlendirme, Gazi Kitapevi 5. Baskı, Ankara, (2005). 